\title{
Radioisotopic tracer technique for characterization of nuclear and non-nuclear grade ion exchange resins Tulsion A-23 and Indion-810
}

\author{
Pravin U. Singare \\ Department of Chemistry, Bhavan's College, Munshi Nagar, Andheri (West), \\ Mumbai 400058, India \\ E-mail address: pravinsingare@gmail.com
}

\begin{abstract}
In the present paper ${ }^{82} \mathrm{Br}$ radioactive tracer isotopes was used for characterization of nuclear and non-nuclear grade ion exchange resins Tulsion A-23 and Indion-810 respectively. The bromide ionisotopic exchange reactions were performed by equilibrating $1.000 \mathrm{~g}$ of conditioned resins in bromide form with labeled bromide ion solution of different concentrations ranging from $0.001 \mathrm{M}$ to $0.004 \mathrm{M}$, in the temperature range of $30.0^{\circ} \mathrm{C}$ to $45.0^{\circ} \mathrm{C}$. The resins were characterized by comparing the values of specific reaction rate $\left(\mathrm{min}^{-1}\right)$, amount of bromide ion exchanged $(\mathrm{mmol})$ and percentage of bromide ions exchanged under identical experimental conditions. It was observed that the above values decrease with rise in temperature and increases with increase in concentration of labeled bromide ion solution. From the experimental values of specific reaction rate, amount and percentage of bromide ions exchanged, it was observed that Tulsion A-23 resins are superior to Indion-810 resins under identical experimental conditions.
\end{abstract}

Keywords: Anion Exchange Resins; Radiotracer Isotopes; Tulsion A-23; Indion-810; Characterization

\section{INTRODUCTION}

Organic ion exchangers have proved to be reliable and effective for the control of both the chemistry and radiochemistry of water coolant systems at nuclear power plants and also for processing some liquid radioactive waste [1,2]. Nuclear power plant process water systems have typically used organic ion exchange resins to control system chemistry, to minimize corrosion or the degradation of system components and to remove radioactive contaminants. Efforts to develop new organic ion exchange resins for specific applications are continuing [3-9]. In spite of their advanced stage of development, various aspects of ion exchange technologies have been continuously studied to improve the efficiency and economy of their application in various industrial applications [10-14]. In order to select the ion exchange resins for any technological application, it is essential to have adequate knowledge about their performance under different operational conditions and also regarding their physical/chemical properties, which forms the complementary part of resin characterization study. Therefore in the present investigation, attempt is made to apply the radioisotopic tracer technique for characterization of nuclear and non-nuclear grade ion exchange resins Tulsion A-23 and Indion-810. 


\section{EXPERIMENTAL}

\section{1. Conditioning of ion exchange resins}

Ion exchange resin Tulsion A-23 (Nuclear grade resins by Thermax India Ltd., Pune), and Indion-810 (Non-nuclear grade resins by Ion Exchange India Ltd., Mumbai) are strongly basic anion exchange resin in hydroxide form. These resins were converted in to bromide form by treatment with $10 \% \mathrm{KBr}$ solution in a conditioning column. The resins were then washed with double distilled water, and then air dried at room temperature. The radioactive tracer isotope ${ }^{82} \mathrm{Br}$ used in the present study is an aqueous solution of ammonium bromide in dilute ammonium hydroxide having $\mathrm{t}_{1 / 2} 36 \mathrm{~h}$, radioactivity $5 \mathrm{mCi}$ and $\gamma$-energy $0.36 \mathrm{MeV}$ [15].

\section{2. Study on kinetics of bromide ion-isotopic exchange reaction.}

In a stoppered bottle $250 \mathrm{~mL}$ of $0.001 \mathrm{M}$ bromide ion solution was labeled with diluted ${ }^{82} \mathrm{Br}$ radioactive solution using a micro syringe, such that $1.0 \mathrm{~mL}$ of labeled solution has a radioactivity of around $15,000 \mathrm{cpm}$ (counts per minute) when measured with $\gamma$-ray spectrometer having NaI (Tl) scintillation detector. Since only about 50-100 $\mu \mathrm{L}$ of the radioactive bromide ion solution was required for labeling the solution, its concentration will remain unchanged, which was further confirmed by potentiometer titration against $\mathrm{AgNO}_{3}$ solution. The above labeled solution of known initial activity was kept in a thermostat adjusted to $30.0^{\circ} \mathrm{C}$. The swelled and conditioned dry ion exchange resins in bromide form weighing exactly $1.000 \mathrm{~g}$ were transferred quickly into this labeled solution which was vigorously stirred by using mechanical stirrer and the activity in cpm of $1.0 \mathrm{~mL}$ of solution was measured. The solution was transferred back to the same bottle containing labeled solution after measuring activity. The bromide ion-isotopic exchange reaction can be represented as:

$$
\mathrm{R}-\mathrm{Br}+\mathrm{Br}^{*-} \text { (aq.) } \longleftrightarrow \mathrm{R}-\mathrm{Br}^{*}+\mathrm{Br}^{-} \text {(aq.) }
$$

Here $\mathrm{R}-\mathrm{Br}$ represents ion exchange resin in bromide form; $\mathrm{Br}^{*^{-}}{ }_{\text {(aq.) }}$ represents aqueous bromide ion solution labeled with ${ }^{82} \mathrm{Br}$ radiotracer isotope.

The activity of solution was measured at a fixed interval of every $2.0 \mathrm{~min}$. The final activity of the solution was also measured after 3 hours which was sufficient time to attain the equilibrium [16-18]. Similar experiments were carried out by equilibrating separately $1.000 \mathrm{~g}$ of ion exchange resin in bromide form with labeled bromide ion solution of four different concentrations ranging up to $0.004 \mathrm{M}$ at a constant temperature of $30.0{ }^{\circ} \mathrm{C}$. The same experimental sets were repeated for higher temperatures up to $45.0^{\circ} \mathrm{C}$.

\section{RESULTS AND DISCUSSION}

In the present investigation it was observed that due to the rapid bromide ion-isotopic exchange reaction taking place, the activity of solution decreases rapidly initially, then due to the slow exchange the activity of the solution decreases slowly and finally remains nearly constant giving rise to a composite curve (Figure 1). The specific reaction rate for the rapid exchange reaction was obtained by resolving the composite curve in the similar way as that explained in our previous work [16-18]. The amount of bromide ions exchanged (mmol) on the resin were obtained from the initial / final activity of solution and the amount of exchangeable bromide ions in $250 \mathrm{~mL}$ of solution. 
From the results it appears that the calculated values of specific reaction rate $\left(\mathrm{min}^{-1}\right)$, amount of bromide ion exchanged ( $\mathrm{mmol}$ ) and percentage of bromide ion exchanged decreases with rise in temperature from $30.0{ }^{\circ} \mathrm{C}$ to $45.0^{\circ} \mathrm{C}$, using $1.000 \mathrm{~g}$ of resins in bromide form and $0.001 \mathrm{M}$ labelled bromide ion solution (Table 1). It was observed that using Tulsion A-23 resin, at $30.0^{\circ} \mathrm{C}$; the above values were obtained as $0.175 \mathrm{~min}^{-1}, 0.128 \mathrm{mmol}$ and 51.3 $\%$; which at $45.0{ }^{\circ} \mathrm{C}$ decreases to $0.155 \mathrm{~min}^{-1}, 0.121 \mathrm{mmol}$ and $48.5 \%$ respectively. Similarly by using Indion- 810 resin, the values calculated were $0.078 \mathrm{~min}^{-1}, 0.065 \mathrm{mmol}$ and $25.8 \%$ at $30.0{ }^{\circ} \mathrm{C}$; which decreases to $0.065 \mathrm{~min}^{-1}, 0.055 \mathrm{mmol}$ and $21.9 \%$ at $45.0{ }^{\circ} \mathrm{C}$ (Table 1 ). The above trend in calculated values was reversed when the experiment was performed by increasing the concentration of labeled bromide ion solution from $0.001 \mathrm{M}$ to $0.004 \mathrm{M}$, at constant temperature of $30.0{ }^{\circ} \mathrm{C}$ using $1.000 \mathrm{~g}$ of resins in bromide form (Table 2). It was observed that for Tulsion A-23 resin, using 0.001 M labelled bromide ion solution the above values were $0.175 \mathrm{~min}^{-1}, 0.128 \mathrm{mmol}$ and $51.3 \%$ which increases to $0.200 \mathrm{~min}^{-1}, 0.530 \mathrm{mmol}$ and $53.0 \%$ for $0.004 \mathrm{M}$ labelled bromide ion solution. Similarly in case of Indion-810 resin, the values calculated were as $0.078 \mathrm{~min}^{-1}, 0.065 \mathrm{mmol}$ and $25.8 \%$ using $0.001 \mathrm{M}$ labelled bromide ion solution; which increases to $0.120 \mathrm{~min}^{-1}, 0.384 \mathrm{mmol}$ and $38.4 \%$ using $0.004 \mathrm{M}$ labelled bromide ion solution (Table 2).

The overall result suggest that the calculated values of specific reaction rate $\left(\mathrm{min}^{-1}\right)$, amount of bromide ion exchanged $(\mathrm{mmol})$ and percentage of bromide ion exchanged were higher for Tulsion A-23 resin as compared to that obtained for Indion-810 resin under identical experimental conditions.

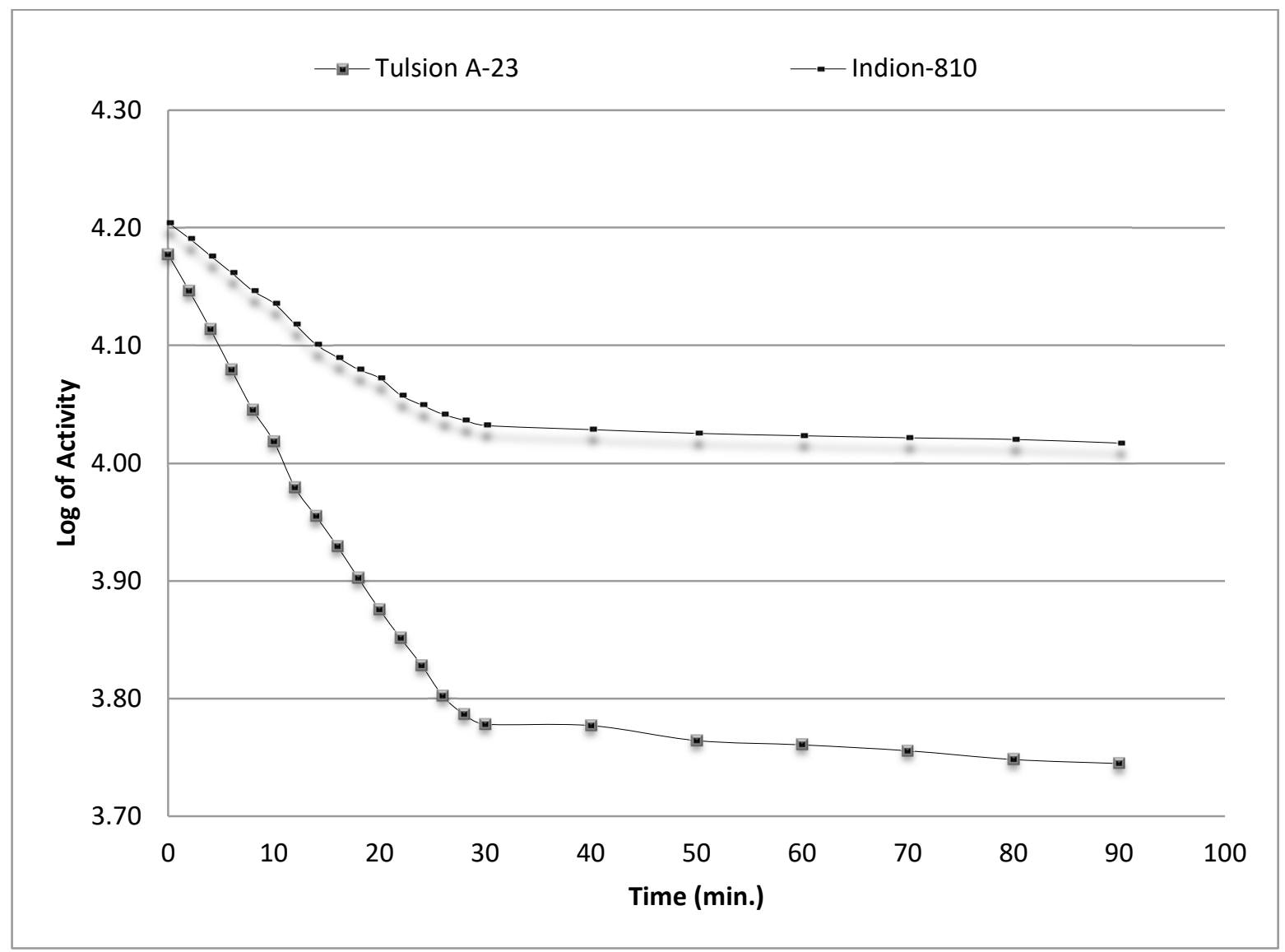

Figure 1. Kinetics of Bromide Ion-Isotopic Exchange Reaction. 
Table 1. Temperature effect on Bromide Ion-Isotopic Exchange Reaction ${ }^{\mathrm{a}, \mathrm{b}, \mathrm{c}, \mathrm{d}}$.

\begin{tabular}{|c|c|c|c|c|c|c|}
\hline \multirow[b]{2}{*}{$\begin{array}{c}\text { Tempe- } \\
\text { rature } \\
\left({ }^{\circ} \mathrm{C}\right)\end{array}$} & \multicolumn{3}{|c|}{ Tulsion A-23 } & \multicolumn{3}{|c|}{ Indion $\mathbf{- 8 1 0}$} \\
\hline & $\begin{array}{l}\text { Specific } \\
\text { reaction rate } \\
\text { of rapid } \\
\text { process } \\
\text { min }^{-1}\end{array}$ & $\begin{array}{c}\text { Amount of } \\
\text { bromide ion } \\
\text { exchanged } \\
(\mathrm{mmol})\end{array}$ & $\begin{array}{c}\% \text { of bromide } \\
\text { ions } \\
\text { exchanged }\end{array}$ & $\begin{array}{l}\text { Specific } \\
\text { reaction rate } \\
\text { of rapid } \\
\text { process } \\
\text { min }^{-1}\end{array}$ & $\begin{array}{c}\text { Amount of } \\
\text { bromide ion } \\
\text { exchanged } \\
(\mathrm{mmol})\end{array}$ & $\begin{array}{c}\% \text { of } \\
\text { bromide } \\
\text { ions } \\
\text { exchanged }\end{array}$ \\
\hline 30.0 & 0.175 & 0.128 & 51.2 & 0.078 & 0.065 & 25.8 \\
\hline 35.0 & 0.164 & 0.125 & 50.0 & 0.072 & 0.060 & 24.0 \\
\hline 40.0 & 0.161 & 0.124 & 49.6 & 0.068 & 0.057 & 22.8 \\
\hline 45.0 & 0.155 & 0.121 & 48.4 & 0.065 & 0.055 & 21.9 \\
\hline
\end{tabular}

${ }^{\mathrm{a}}$ Amount of ion exchange resin in bromide form $=1.000 \mathrm{~g}$.

${ }^{\mathrm{b}}$ Concentration of labeled bromide ion solution $=0.001 \mathrm{M}$.

${ }^{\mathrm{c}}$ Volume of labeled bromide ion solution $=250 \mathrm{~mL}$.

${ }^{\mathrm{d}}$ Amount of exchangeable bromide ions in $250 \mathrm{~mL}$ labeled solution $=0.250 \mathrm{mmol}$.

Table 2. Concentration effect on Bromide Ion-Isotopic Exchange Reaction ${ }^{\mathrm{a}, \mathrm{b}, \mathrm{c}}$.

\begin{tabular}{|c|c|c|c|c|c|c|c|}
\hline \multirow[b]{2}{*}{$\begin{array}{c}\text { Conce- } \\
\text { ntration } \\
\text { of } \\
\text { bromi- } \\
\text { de ion } \\
\text { solution } \\
\text { (M) }\end{array}$} & \multirow[b]{2}{*}{$\begin{array}{c}\text { Amount } \\
\text { of } \\
\text { bromide } \\
\text { ions in } \\
200 \mathrm{~mL} \\
\text { solution } \\
\text { (mmol) }\end{array}$} & \multicolumn{3}{|c|}{ Tulsion A-23 } & \multicolumn{3}{|c|}{ Indion -810 } \\
\hline & & $\begin{array}{l}\text { Specific } \\
\text { reaction } \\
\text { rate of } \\
\text { rapid } \\
\text { process } \\
\text { min-1 }\end{array}$ & $\begin{array}{c}\text { Amount } \\
\text { of } \\
\text { bromide } \\
\text { ion } \\
\text { exchan- } \\
\text { ged } \\
\text { (mmol) }\end{array}$ & $\begin{array}{c}\% \text { of } \\
\text { bromide } \\
\text { ions } \\
\text { exchan- } \\
\text { ged }\end{array}$ & $\begin{array}{c}\text { Specific } \\
\text { reaction } \\
\text { rate of } \\
\text { rapid } \\
\text { process } \\
\text { min-1 }\end{array}$ & $\begin{array}{l}\text { Amount of } \\
\text { bromide } \\
\text { ion } \\
\text { exchanged } \\
\text { (mmol) }\end{array}$ & $\begin{array}{c}\% \text { of } \\
\text { bromi- } \\
\text { de ions } \\
\text { excha- } \\
\text { nged }\end{array}$ \\
\hline 0.001 & 0.250 & 0.175 & 0.128 & 51.2 & 0.078 & 0.065 & 26.0 \\
\hline 0.002 & 0.500 & 0.179 & 0.257 & 51.4 & 0.091 & 0.149 & 29.8 \\
\hline 0.003 & 0.750 & 0.195 & 0.394 & 52.5 & 0.107 & 0.260 & 34.7 \\
\hline 0.004 & 1.000 & 0.200 & 0.530 & 53.0 & 0.120 & 0.384 & 38.4 \\
\hline
\end{tabular}

${ }^{\mathrm{a}}$ Amount of ion exchange resin in bromide form $=1.000 \mathrm{~g}$.

${ }^{\mathrm{b}}$ Volume of labeled bromide ion solution $=250 \mathrm{~mL}$.

${ }^{\mathrm{c}}$ Temperature $=30.0^{\circ} \mathrm{C}$. 


\section{CONCLUSION}

The experimental work carried out in the present investigation will help to standardize the operational process parameters so as to improve the performance of selected nuclear grade ion exchange resins.

The radioactive tracer technique used here can also be applied for characterization of different nuclear as well as non-nuclear grade ion exchange resins.

\section{References}

[1] Matsuda M., Funabashi K., Yusa H., J. Nuclear Science and Technology 24 (1987) 124.

[2] Matsuda M., Funabashi K., Kawamura F., Uchida S., Ohsumi K., Nucl. Technol. 78 (1987) 62.

[3] Xuejun L., Yiming X., Kangle L., Gencheng Z., J. Photochemistry and Photobiology 173 (2005) 121.

[4] Buscher C., Donohoe R., Mecklenburg S., Berg J., Tait C., Huchton K., Morris D., Applied Spectroscopy 53 (1999) 943.

[5] Van Loon L., Hummel W., Nuclear Technology 128 (1999) 388.

[6] Tulupov P., Polyanskii N., Russian Chemical Reviews 42 (1999) 107.

[7] McConnell Jr. J., Johnson D., Sanders Sr. R., Waste Management 13 (1993) 65.

[8] Zahorodna M., Bogoczek R., Oliveros E., Braun A., Catalysis Today 129 (2007) 200.

[9] Bolma A., Icemenerg A., Bucharest D., Power Tech. 1 (2005) 1.

[10] Iwai Y., Yamanishi T., Hiroki A., Tamada M., Fusion Science and Technology $56(2009) 163$.

[11] Gonder Z., Kaya Y., Vergili I., Barlas H., Aachen Membrane Colloquium 189 (2006) 303.

[12] Chambree D., Cornelia I., Segal E., Cesro A., J. Thermal Analysis and Calorimetry 82 (2005) 3.

[13] Ichikawa T., Hagiwara Z., J. Nuclear Science and Technology 10 (2004) 746.

[14] Simister C., Caron F., Gedye R., J. Radioanalytical and Nuclear Chemistry 261 (2004) 523.

[15] Sood D., Proc. Int. Conf. on Applications of Radioisotopes and Radiation in Industrial Development, B.A.R.C., Mumbai 1998, p 35.

[16] Lokhande R., Singare P., Tiwari S., Russ. J. Physical Chemistry 83 (2009) 1389.

[17] Lokhande R., Singare P., Kolte A., Radiochim. Acta 95 (2007) 595.

[18] Lokhande R., Singare P., Dole M., J. Nuclear and Radiochemical Sciences 7 (2006) 29. 